\title{
ISTILAH 'REMPIT'; PENGERTIAN DAN PENGGUNAANNYA DALAM ISU LUMBA MOTORSIKAL HARAM DI MALAYSIA
}

\author{
Rozmi Ismail \& Boekhtiar Borhanuddin \\ Pusat Pengajian Psikologi dan Pembangunan Manusia, \\ Fakulti Sains Sosial dan Kemanusiaan Universiti Kebangsaan Malaysia \\ Email: rozmi@ukm.edu.my
}

\begin{abstract}
Rempit term (race) is very popular in Malaysia to use for identifying illegal motorcycle race. This research aimed to know the uses of rempit concept in the Mat Rempit group itself. The Study using 2 types of interview, the first is individual interview with 16 subjects whom had involved in rempit activity in a school at Semenyih, Selangor; the second is focus group discussion consist of 3 groups of defendant under section 42 as a result of riding motorcyle dongerously in Pulau Pinang, Johor Baharu and Kuala Lumpur. Result of the analysis, found that rempit can be redefine as an activity of motorcycle race as together (at least consist of 2 persons) which involves race (i.e sprint or lap) and/or stunt action (i.e wheelie or wheekang) triggered by trial behavior trough engine signal from motorcycle (ramp), communication or hand gesture. A Mat Rempit (racer) is an individu who get involved in this activity. This research reviews the definition throughly by formulating rempit activity comprehensively. The implication of the research is rempit word has to be used cautiosly, especially when trying to give a label to an individual as Mat Rempit. For the future research, the definition that has to be used is the one which proposed in this research and not other vague definition.
\end{abstract}

Key words: Rempit, Teenager, Illegal Motorcycle Race, Acrobatic Stunt

\begin{abstract}
Abstrak
Perkataan Rempit sangat popular di Malaysia bagi merujuk kepada aktiviti berlumba motor secara haram. Kajian ini bertujuan mengimbas semula penggunaan konsep rempit daripada golongan yang dianggap Mat Rempit sendiri. Kajian ini menggunakan dua kaedah temuramah, iaitu secara temuramah individual yang melibatkan 16 individu yang pernah terlibat dengan aktiviti rempit daripada sebuah sekolah di Semenyih, Selangor; serta secara temuramah kumpulan fokus yang melibatkan 3 kumpulan individu yang didakwa di bawah Seksyen 42 akibat memandu motorsikal secara berbahaya di Pulau Pinang, Johor Baharu dan Kuala Lumpur. Hasil daripada analisis temuramah yang dijalankan, pengkaji mendapati rempit boleh didefinisikan sebagai sebarang aktiviti pertandingan motorsikal secara berkumpulan (sekurang-kurang 2 orang) yang melibatkan perlumbaan (seperti sprint atau lap) dan aksi stunt (seperti wheelie atau wheekang) yang dicetuskan secara fizikal oleh perbuatan cabar-mencabar melalui isyarat bunyi enjin motor (ramp), percakapan atau isyarat tangan. Seorang Mat Rempit adalah individu yang terlibat dalam aktiviti ini. Kertas ini mengulas definisi ini dengan lebih terperinci dengan merumuskan aktiviti rempit secara komprehensif. Implikasi kajian ini ialah penggunaan perkataan rempit harus lebih berhati-hati khususnya semasa membuat penglabelan individu yang dianggap Mat Rempit. Sebarang kajian yang akan datang seharusnya merujuk kepada definisi yang dicadangkan ini dan bukannnya berdasarkan definisi yang kabur.
\end{abstract}

Kata-kata kunci: Rempit, remaja, lumba motor haram, aksi akrobatik. 
$\mathrm{S}$ iapakah sebenarnya individu yang bergelar Mat Rempit? Pada hakikatnya, istilah 'Mat Rempit' tidak wujud dalam kamus Bahasa Malaysia. Perkataan 'Mat Rempit' sebenarnya diperkenalkan dan dipopularkan oleh media massa Malaysia yang mendedahkan fenomena kegilaan pembabitan anak muda dalam kegiatan lumba haram motorsikal pada suatu masa dahulu (Berita Harian 6 November 2006). Fokus sebenar kertas kerja ini adalah bagi menyemak semula definisi konsep 'rempit' yang diguna-pakai di Malaysia.

Secara umumnya, perkataan 'rempit' kemungkinan diambil daripada bahasa Inggeris, iaitu ramp-it yang menggambarkan pelumba memeras minyak di jalan raya (litar) yang akhirnya menjadi nama jolokan kepada kumpulan terlibat (Rozmi 2004). Menurut satu lagi definisi berdasarkan Kamal Affendi (Berita Harian 6 November 2006), istilah 'rempit' bermula daripada gabungan 'rem' dan 'pit'. Perkataan 'rem' merujuk kepada pelakuan memerah minyak bagi menguji kuasa enjin yang sering dilakukan oleh penunggang motosikal, manakala 'pit' pula merujuk pada litar lumba, iaitu 'pit stop'. Hasil gabungan kedua-dua perkataan mewujudkan istilah 'rempit' yang akhirnya menjadi sebutan umum sehingga kini. Selain pendefinisian di atas istilah Mat Rempit juga merujuk kepada individu yang menyertai perlumbaan haram menggunakan motorsikal berkuasa kecil (Rozmi, 2004; Rozmi, 2005). Terdapat juga kemungkinan bahawa istilah Mat Rempit ini berasal daripada perkataan 'himpit'. Ini kerana semasa menunggang motosikal, anak-anak muda ini akan berhimpit-himpit untuk mara kehadapan, mencelah, mencelok dan mengelencong untuk memotong kenderaan yang lebih besar.

Draf artikel daripada kajian terbaru oleh Rozmi et al (2009) pula memberikan beberapa ciri-ciri bagi menganggap seseorang individu itu sebagai seorang Mat Rempit, iaitu i) Daripada golongan remaja; ii) Menggunakan motosikal berkuasa rendah; iii) Terlibat dengan perlumbaan haram; iv) Berlumba melibatkan pertaruhan atau tidak; v) Melakukan aktiviti dalam kumpulan sendiri; vi) Mempunyai struktur kumpulan yang tidak formal; vii) Mempunyai sub budaya yang tersendiri; dan viii) Melakukan aksi berbahaya dan mengganggu ketenteraman awam. Daripada kajian yang terbaru ini, kita dapati bahawa Mat Rempit sebenarnya mempunyai fenomena yang tersendiri, di mana mereka yang terlibat dengan fenomena ini tidak semestinya penunggang motorsikal yang 'merempit' yang dianggap hardcore, tetapi juga melibatkan penonton yang terlibat secara aktif dalam aktiviti dan acara Mat Rempit. Daripada sudut undangundang pula, istilah Mat Rempit mempunyai definisi yang jauh lebih kabur. Individuindividu yang terlibat dalam fenemona ini mungkin ditahan di bawah Seksyen 42 Akta Pengangkutan Jalan 1987 di mana mereka boleh didakwa menunggang motorsikal secara bahaya. Terdapat desas-desus daripada Menteri Pengangkutan Malaysia bahawa kerajaan akan meminda Akta Pengangkutan Jalan selewatlewatnya akhir tahun ini bagi menyekat aktiviti Mat Rempit (Utusan Online 2009). Pada masa yang sama, pihak Polis Diraja Malaysia (PDRM) telah mencadangkan supaya perkataan Mat Rempit perlu dihapuskan dan digantikan dengan nama 'samseng jalan raya'. Menurut PDRM jolokan Mat Rempit boleh menjadi unsur kebanggaan kepada golongan ini yang akan menggalakkan lagi aktiviti yang bersifat negatif (Utusan Malaysia 20 Mei 2009).

Sejurus dengan kepelbagaian definisi yang digunakan bagi konsep 'rempit', maka pengkaji menjadikan pendefinisian semula konsep 'rempit' sebagai fokus kajian ini. Pendefinisian semula ini cuba memberikan kriteria yang lebih jelas dan lengkap bagi membolehkan sebarang kajian akan datang dapat mengenalpasti individu yang digelar sebagai 'Mat Rempit' secara operasional. Bagi tujuan ini, pengkaji telah menjalankan kajian yang berbentuk kualitatif bagi melihat apakah yang dimaksudkan dengan 'rempit' serta aktiviti-aktiviti yang berkaitan dengannya daripada inidividu-individu yang pernah terlibat dengan aktiviti yang dianggap 'rempit' itu sendiri. Pendefinisian bercorak fenomenalogikal ini (Smith \& Eatough 2007) diharap dapat mengelakkan pengaruh 
pendefinisian oleh masyarakat yang bersifat out-group.

\section{METODE}

Kajian ini melibatkan beberapa siri temuramah mendalam yang melibatkan temuramah focus-group dan temuramah individual. Temuramah focus-group melibatkan 3 kumpulan subjek di Pulau Pinang, Johor Baharu dan Kuala Lumpur yang terdiri daripada mereka yang pernah ditahan di bawah Seksyen 42 kerana memandu motorsikal secara berbahaya. Teknik persampelan yang digunakan bagi focus-group adalah secara purposive di mana pihak polis di kawasankawasan terbabit memberikan kerjasama kepada pengkaji dengan meminta individu yang dalam proses pendakwaan akibat pelanggaran Seksyen 42 menjadi sukarelawan bagi tujuan temuramah. Temuramah ini melibatkan 1 sesi temuramah (selama 30-45 minit setiap sesi) bagi setiap kumpulan yang dianggotai 4 hingga 5 orang, di mana setiap subjek dibayar saguhati RM10. Temuramah individual pula melibatkan 16 subjek pelajar Tingkatan 3 hingga 5 di sebuah sekolah menengah di Semenyih, Selangor yang terdiri daripada subjek yang pernah terlibat dan masih terlibat dengan aktiviti Mat Rempit. Teknik persampelan yang digunakan bagi kumpulan individual adalah secara purposive dan snow-ball dengan bantuan pihak kaunselor sekolah terbabit yang mengenal pasti pelajar-pelajar yang sesuai bagi kajian ini. Sesi temuramah individual melibatkan antara 3 hingga 13 sesi temuramah (selama 1 jam setiap sesi) bagi setiap subjek yang dijalankan dalam tempoh 4 bulan, di mana setiap subjek dibayar saguhati RM20 bagi setiap sesi. Borang persetujuan menyertai kajian telah didapatkan daripada semua subjek kajian.

Setiap sesi temuramah telah dijalankan oleh seorang penemuramah terlatih secara semi-berstruktur serta direkod secara audio dan catatan lapangan. Bagi tujuan kertas kerja ini, analisis hanya dilakukan melalui catatan lapangan di mana penemuramah membuat catatan bagi salient points aktiviti yang dianggap 'rempit' oleh subjek. Analisis dilakukan dengan tangan bagi pengelompokan aktiviti-aktiviti dan penerangannya dalam tema-tema tertentu. Definisi konsep 'rempit' yang terbentuk daripada analisis kemudiannya dibincangkan dengan 3 subjek temuramah individual (yang merupakan Mat Rempit tegar) bagi divalidasi oleh mereka dan dilakukan pembetulan.

\section{HASIL}

Daripada analisis, Rempit boleh didefinisikan sebagai sebarang aktiviti pertandingan motorsikal secara berkumpulan (sekurang-kurang 2 orang) yang melibatkan perlumbaan (seperti sprint atau lap) dan/atau aksi stunt (seperti wheelie atau wheekang) yang dicetuskan secara fizikal oleh perbuatan cabarmencabar melalui isyarat bunyi enjin motor (ramp), percakapan atau isyarat tangan. Seorang Mat Rempit adalah individu yang terlibat dalam aktiviti ini. Oleh itu kesemua kriteria berikut perlu wujud bagi mengatakan seseorang individu itu sebagai Mat Rempit, iaitu i) Penglibatan dalam aktiviti pertandingan motorsikal secara berkumpulan (sekurangkurangnya 2 orang); ii) Penglibatan dalam aktiviti yang melibatkan perlumbaan dan/atau aksi stunt; dan iii) Aktiviti terbabit melibatkan perbuatan cabar-mencabar. Penerangan kriteria serta perkara-perkara yang berkaitan diterangkan satu persatu dalam bahagian seterusnya.

\section{a) Huraian Aktiviti Pertandingan Motorsikal Secara Berkumpulan}

Pertandingan ini boleh terjadi sama ada secara dirancang terlebih dahulu dan juga secara tidak dirancang (on-the-spot), sama ada pada waktu siang atau malam. Terdapat 3 bentuk pertandingan motorsikal secara berkumpulan, iaitu: i) Pertandingan antara rakan-rakan atau kenalan dalam suatu kawasan; ii) Pertandingan antara dua atau lebih kumpulan bermotorsikal informal (yang terdiri daripada kumpulan-kumpulan rakan yang berlainan, sama ada daripada satu kawasan yang sama atau daripada kawasan yang berlainan); atau iii) Pertandingan antara dua atau lebih kumpulan bermotorsikal formal 
(yang terdiri daripada ahli kumpulan bermotorsikal yang mempunyai struktur keahlian yang formal, sama ada di peringkat kebangsaan atau kawasan). Kumpulan bermotorsikal formal ini mempunyai borang keahlian masing-masing yang perlu disi untuk direkod, di mana setiap ahli akan diberikan pelekat rasmi serta kad rasmi kumpulan terbabit (yang perlu dibuat bayaran). Sebahagaian daripada kumpulan bermotorsikal ini adalah pertubuhan berdaftar secara rasmi (seperti kumpulan Shell) dan sebahagaiannya pula adalah secara haram (seperti Apache).

\section{b) Huraian Aktiviti Yang Melibatkan} Perlumbaan Dan/Atau Aksi Stunt

Perlumbaan yang dilakukan adalah berobjektif melihat siapa yang dapat membawa motorsikal secara paling laju (kelajuan yang digunakan adalah antara 120-170 km/jam). Bentuk-bentuk perlumbaan yang terjadi adalah: i) Sprint test - Perlumbaan secara laluan lurus; ii) Main angin (Perlumbaan secara zig-zag, di mana pelumba akan mengekori satu sama lain sebelum cuba memotong sesama sendiri pada masa yang sesuai); iii) Main lap - Perlumbaan yang melibatkan jalan raya yang mempunyai selekoh; dan iv) Main roundabout Perlumbaan yang melibatkan pusingan berulang-ulang di bulatan jalan. Bagi aksi stunt pula ianya dilakukan dengan berobjektif melihat siapa yang dapat melakukan aksi stunt secara paling lama (ukuran adalah berdasarkan berapa tiang yang lampu jalan yang dapat dilepasi). Bentuk-bentuk aksi stunt yang terjadi adalah: i) Wheelie - Menunggang motorsikal dengan mengangkat tayar hadapan (boleh dilakukan secara seorang, berdua atau lebih pada satu motorsikal); ii) Wheekang Menunggang motorsikal dengan mengangkat tayar belakang; atau iii) Aksi Superman Menunggang motorsikal secara berbaring melintang seakan-akan terbang, tanpa meletakkan kaki di brek kaki atau di gear.

\section{c) Huraian Perbuatan Cabar Mencabar Semasa Pertandingan}

Perbuatan cabar-mencabar secara fizikal yang mencetuskan aktiviti rempit boleh dilakukan melalui: i) Isyarat bunyi enjin motor (ramp) - Individu atau kumpulan yang mencabar akan melakukan ramp sekuatkuatnya di hadapan individu atau kumpulan yang hendak dicabarnya untuk bertanding. Isyarat ramp juga boleh dilakukan secara indirect dengan pencabar melakukan ramp sekuat-kuatnya semasa menunggang motorsikal dengan laju di suatu kawasan untuk mencabar sebarang penunggang lain yang boleh mendengarnya; ii) Percakapan- Individu atau wakil kumpulan yang mencabar akan pergi sendiri untuk berundin ke individu atau kumpulan yang hendak dicabarnya untuk bertanding. Cabaran ini boleh berlaku sama ada dengan nada baik atau dengan nada biadap (mengejek); atau iii) Isyarat tangan- Individu atau wakil kumpulan yang mencabar akan memetik jari ke arah individu atau kumpulan yang hendak dicabarnya untuk bertanding. Semasa memetik jari ini, pencabar boleh dalam keadaan menunggang motorsikal dengan laju ataupun semasa berhenti.

\section{d) Matlamat Pertandingan}

Pertandingan yang dilakukan mempunyai salah-satu matlamat berikut: i) Main kosong- Pertandingan tidak melibatkan sebarang ganjaran material, hanya mendapat kepuasan dan nama "baik" sahaja; ii) Main duit- Pertandingan melibatkan ganjaran wang (dalam nilai ratusan hingga ribuan ringgit); iii) Taruhan motorsikal- Pertandingan melibatkan taruhan motorsikal yang ditunggang oleh mereka yang terlibat dalam pertandingan. Ini biasanya dilakukan jika motorsikal tersebut adalah jenis motorsikal curi; iv) Main bakar motor- Pertandingan melibatkan pembakaran motorsikal penunggang yang kalah dalam pertandingan terbabit. Ini biasanya dilakukan jika motorsikal tersebut adalah jenis motorsikal curi; atau v) Ganjaran perempuanPertandingan jenis ini adalah jarang dan biasanya melibatkan bohsia yang menawarkan diri kepada pemenang pertandingan.

\section{e) Sebab-Sebab Terlibat Dalam Aktiviti Rempit Yang Dilaporkan Subjek}


Berikut adalah sebab-sebab utama yang dilaporkan oleh subjek-subjek tentang sebab utama mereka terlibat dalam aktiviti rempit; iaitu i) Akibat kebosanan; ii) Perasaan seronok semasa merempit; iii) Rasa 'hati terbakar' apabila dicabar penunggang lain; dan iv) Untuk mendapatkan pengiktirafan 'status tinggi' daripada penunggang lain di mana subjek rasa bangga dan hebat pada diri.

\section{PEMBAHASAN}

Berdasarkan dapatan kajian ini adalah amat jelas bahawa wujud perbezaan daripada segi definisi 'rempit' antara apa yang dimaksudkan oleh khalayak dan media massa berbanding dengan apa yang dimaksudkan oleh golongan 'Mat Rempit' itu sendiri. Perkataan 'rempit' oleh khalayak ramai mempunyai konotasi yang negatif, manakala bagi Mat Rempit pula perkataan terbabit mempunyai konotasi neutral. Walaupun tingkah laku 'rempit' daripada segi perlumbaan haram serta tingkah laku membunyikan enjin motorsikal dengan kuat boleh dianggap sebagai perbuatan yang mengganggu orang lain, tetapi bagi Mat Rempit tingkah laku terbabit dianggap sebagai bersifat 'peribadi' sahaja. Beberapa subjek yang ditemuramah mengatakan bahawa mereka tidak berpuas hati dengan cemuhan masyarakat kerana mereka menganggap 'rempit' merupakan suatu aktiviti yang 'sah' kerana menganggap ianya tiada kaitan dengan jenayah. Mereka berpendapat masyarakat tidak mempunyai hak untuk mengadili mereka kerana masyarakat membuat kesimpulan yang terlapau simplistik. Salah seorang subjek berkata: "Kenapa Mat Rempit selalu disalahkan?... Ingat perompak bank tu pakai motor ke? ... Dia orang pakai kereta... Tapi kenapa orang pakai kereta tak disalahkan?" Di sini pengkaji agak bersetuju dengan apa yang subjek cuba sampaikan. Kemungkinan besar masyarakat mempunyai bias yang tertentu hasil daripada penggunaan heuristiks keperolehan (availability heuristics) dan heuristiks perwakilan (representative heuristics). Kita berkemungkinan lebih mengaitkan Mat Rempit dengan aktiviti jenayah akibat media massa memperbesarkan isu ini. Tapi pada masa sama, pendapat subjek terbabit juga perlu dipertimbangkan dengan berhati-hati memandangkan wujud kemungkinan selfserving bias di sini semasa temuramah. Pengkaji mendapati subjek-subjek kajian yang terlibat dalam temuramah individual mempunyai semangat yang 'berkobar-kobar' untuk menjelaskan kepada pengkaji tentang siapa sebenarnya Mat Rempit. Beberapa subjek menjadi sangat emosional semasa mempertahankan aktiviti 'rempit' apabila pengkaji cuba menawarkan pandangan alternatif tentang isu terbabit (contohnya, aktiviti 'ramp' yang mengganggu ketenangan orang lain pada waktu malam) - "Peduli merekalah!", kata salah seorang subjek dengan nada melenting. Di sini, wujud kemungkinan perbezaan realiti sosial antara masyarakat umum serta bagi individu yang dianggap (serta menganggap) diri mereka mereka sebagai 'Mat Rempit'. Kemungkinan seorang Mat Rempit mempunyai cognitive distortion atau herotan kognitif semasa mempersepsi tindakan yang dianggapnya tidak salah. Pada masa yang sama, tidak dapat diketahui sama ada subjek sebenarnya menipu atau tidak memandangkan kajian lebih berfokus kepada kebenaran naratif (narrative truth) dan bukannya kebenaran sejarah (historical truth) yang memerlukan pengkaji berjumpa dengan individu-individu dalam hidup subjek yang dapat menvalidasi apa yang diceritakan oleh subjek (Spence 1984).

Memandangkan kajian ini adalah bersifat kualitatif yang menggunakan bilangan sampel yang sedikit dan bertumpu kepada 4 lokasi sahaja, maka hasil kajian ini adalah lebih bersifat preliminary yang dapat membuka jalan kepada kajian-kajian kuantitatif lain yang menggunakan saiz sampel yang lebih besar dan representatif. Kriteria definisi yang telah dicadangkan dalam kajian ini perlu disahkan sebagai universal bagi kebanyakan 'Mat Rempit' di seluruh Malaysia sebelum ia dapat digunakan dengan yakin bagi mengkaji fenomena Mat Rempit. Hal ini akan membolehkan pengfokusan kumpulan sasaran bagi sebarang kajian yang akan datang dapat dibuat dengan lebih tepat dan bukannnya berdasarkan definisi yang kabur dan dicorakkan oleh definisi masyarakat yang bersifat outgroup. Selain itu, pemerhatian sampingan 
74 Talenta, Vol. 1 No. 1

kajian ini menunjukkan bahawa wujudnya kebarangkalian herotan kognitif pada sebahagian subjek 'Mat Rempit'. Mungkin akan timbul masalah bagi kajian berbentuk survei jika subjek terbabit mengherotkan realitinya (secara sedar atau tidak) semasa menjawab borang soal selidik dan mengganggu reliabiliti dapatan kajian.

\section{Penghargaan}

Kajian ini sebahagiannya dibiayai oleh dana GUP UKM-GUP-08-268

\section{DAFTAR RUJUKAN}

Berita Harian. 6 November 2006.

Rozmi Ismail, Mohamad Fauzi Sukimi, Rokiah Ismail, Norhayati Ibrahim \& Normah Che Din (2009). Tingkah laku agresif dan aktiviti jenayah di kalangan Mat Rempit. (Draf laporan akhir projek UKM-GUP-08268).

Rozmi Ismail (2005). Perlumbaan motorsikal haram di kalangan remaja. Prosiding Seminar Penyelidikan dan Pembangunan Generasi Muda UKM-KBS, hlm. 315-326.

Rozmi Ismail (2014). Fenomena Lumba Haram di Malaysia; Isu dan Cabaran. Penerbit UKM Press.

Rozmi Ismail (2004). Gejala perlumbaan haram di kalangan remaja; Satu kajian memahami faktor penglibatan dan jenis personaliti pelumba. Prosiding Seminar Kebangsaan ke-3 Psikologi dan Masyarakat: Gejala Sosial dalam Masyarakat, hlm.1-36.

Smith, J. \& Eatough, V (2009). Interpretative phenomenological analysis. ms 35-50. Dalam: Lyons, E. \& Coyle, A. 2009. Analysing qualitative data in psychology. Sage Publications: Los Angeles.

Spence, D. (1984). Narrative truth and historical truth: Meaning and interpretation in psychoanalysis. W. W. Norton and Company: New York.

Utusan Online. (2009). Akta Pengangkutan Jalan dipinda.

http://www.utusan.com.my/utusan/info.asp?y=
Istilah "Rempit": Pengertian dan Penggunaannya

$2009 \& \mathrm{dt}=0509 \& \mathrm{pub}=\mathrm{utusan} \_$malaysia $\& \mathrm{sec}=$ Dalam_Negeri\&pg=dn_20.htm\&arc=hive [21 Mei 2009].

Utusan Malaysia 20 Mei 2009. 